\title{
Ir/ZSM-5/cordierite monolith for catalytic NOx reduction from automobile exhaust
}

\author{
Landong $\mathrm{Li}^{\text {a,b }}{ }^{\text {, Fuxiang Zhang }}{ }^{\mathrm{a}}$, Naijia Guan ${ }^{\mathrm{a}, *}$ \\ ${ }^{a}$ Institute of New Catalytic Materials Science, College of Chemistry, Nankai University, Weijin Road 94, Tianjin 300071, PR China \\ ${ }^{\mathrm{b}}$ Research Center for Eco-Environmental Science, Chinese Academy of Science, Beijing 100085, PR China
}

Received 19 December 2006; received in revised form 7 April 2007; accepted 10 April 2007

Available online 30 April 2007

\begin{abstract}
Ir/ZSM-5/cordierite was studied as promising catalyst for the reduction of nitrogen oxides from automobile exhaust under both stoichiometric combustion and lean conditions. ZSM-5 was in situ synthesized on the surface of honeycomb cordierite substrate and iridium was introduced to ZSM-5/cordierite by wet impregnation. Under stoichiometric combustion, Ir/ZSM-5/cordierite exhibited good catalytic activity approaching commercial three-way catalysts, and the three main pollutants nitrogen oxides, carbon monoxide and unburned hydrocarbons could be purified simultaneously. Under lean conditions, Ir/ZSM-5/cordierite also exhibited quite good deNOx activities though excess oxygen showed inhibition effect on NOx reduction.
\end{abstract}

(c) 2007 Elsevier B.V. All rights reserved.

Keywords: Ir/ZSM-5/cordierite; Automobile exhaust; NOx

\section{Introduction}

The automobile exhaust contains various pollutants: nitrogen oxides, carbon monoxide, unburned hydrocarbons and so on. One of the most urgent problems is the removal of nitrogen oxides, which greatly contribute to the formation of photochemical smog and acid rain [1]. Based on noble metal Pt, Pd and $\mathrm{Rh}$ as main active ingredients, three way catalysts (TWC) can provide high level of emission control for nitrogen oxides, carbon monoxide and unburned hydrocarbons. Up to now, TWC have been proved to be efficient and reliable [2,3], and considered as optimal means to treat the exhaust under the condition of stoichiometric combustion. Current strategies attempting at minimizing of fuel consumption and $\mathrm{CO}_{2}$ emission prompt the use of lean burn engine. However, TWC suffer from severe loss of activity for NOx reduction in the presence of excess oxygen, which is the prevalent condition for lean burn gasoline engines [4].

\footnotetext{
${ }^{*}$ Corresponding author. Tel./fax: +862223500341.

E-mail address: guannj@nankai.edu.cn (N. Guan).
}

Many efforts have been carried out to develop alternative catalysts for NOx reduction in excess oxygen $[6,7,5,8-10]$. Ir-based catalysts have been reported be good catalysts for NOx reduction and received much attention from both experimental [11-15] and theoretical [16-18]. However, the loss of active component iridium is a serious problem to be solved, which prevents Ir-based catalysts from industry application. Correspondingly, no detailed engine test results on Ir-based catalysts are available up to now.

In this work, a promising monolithic catalyst Ir/ZSM-5/ cordierite is prepared for the reduction of NOx from automobile exhaust under both stoichiometric combustion and lean conditions. The detailed engine test results will be reported and the reaction mechanism will also be discussed.

\section{Experimental section}

\subsection{Catalysts preparation}

\subsubsection{In situ synthesis of ZSM-5/cordierite}

The detailed synthesis process of ZSM-5/cordierite has been described in our previous work [19]. In brief, sodium 
hydroxide, aluminum sulfate, silica sol and water were mixed with this proportion: $1 \mathrm{Al}_{2} \mathrm{O}_{3}: 84 \mathrm{SiO}_{2}: 10 \mathrm{Na}_{2} \mathrm{O}$ : $3500 \mathrm{H}_{2} \mathrm{O}$. After vigorous stirring for $2 \mathrm{~h}$, the gained transparent gel and honeycomb cordierite (Corning incorporated, 100 cells $/ \mathrm{cm}^{2}, 0.2 \mathrm{~mm}$ average wall thickness) were put into a high-pressure autoclave together for static crystallization at $180^{\circ} \mathrm{C}$ for $16 \mathrm{~h}$. Subsequently, the as-prepared NaZSM-5/cordierite were taken out, ion-exchanged to $\mathrm{H}$ form by $0.5 \mathrm{M} \mathrm{NH} \mathrm{Nl}_{4} \mathrm{Cl}$, dried at $100{ }^{\circ} \mathrm{C}$ over night and then calcined at $400{ }^{\circ} \mathrm{C}$ for $6 \mathrm{~h}$ in air.

\subsubsection{Preparation of $I r / Z S M-5 /$ cordierite by impregnation}

Ir/ZSM-5/cordierite was prepared from HZSM-5/cordierite by wet impregnation. Different from conventional impregnation process, an ultra weak aqueous solution of $\mathrm{H}_{2} \mathrm{IrCl}_{6} \cdot 6 \mathrm{H}_{2} \mathrm{O}(2 \mathrm{mM})$ was used to improve the dispersion and stability of coated iridium this study. In a typical synthesis, $200 \mathrm{~g} \mathrm{HZSM}-5 /$ cordierite was placed into $200 \mathrm{~mL}$ $2 \mathrm{mM} \mathrm{H}_{2} \mathrm{IrCl}_{6} \cdot 6 \mathrm{H}_{2} \mathrm{O}$ aqueous solution. Under slowly stirring, the solution was evaporated in vacuum at the constant temperature of $60^{\circ} \mathrm{C}$. Then the obtained Ir/ZSM-5/ cordierite sample was dried at $100^{\circ} \mathrm{C}$ over night and calcined in flowing air at $600{ }^{\circ} \mathrm{C}$ for $4 \mathrm{~h}$ before use.

\subsection{Catalysts characterization}

The crystallinity of the synthesized Ir/ZSM-5/cordierite was given by XRD data collected with a Rigaku D/max 2500 diffractometer, equipped with a graphite monochromator and using $\mathrm{Cu} K \alpha$ radiation.

SEM from a HITACHI S-3500N scanning electron microscope detected the surface feature of Ir/ZSM-5/cordierite monolith. TEM images were acquired on a JEOL 2010 transmission electron microscope at an accelerate voltage of $200 \mathrm{kV}$. The particles obtained after the irradiation and workup were dropped onto the surface of carbon membrane and dried at ambient conditions.

Surface areas and pore diameters were determined by nitrogen adsorption on the ASAP $2010 \mathrm{M}$ facility (Micromeritics).

ZSM-5 loading in ZSM-5/cordierite was determined by calculating the weight increase of cordierite after hydrothermal synthesis. The iridium loading in Ir/ZSM-5/cordierite was determined by ICP (IRIS Advantage, TJA solution).

\subsection{Catalytic testing}

Catalytic evaluation experiments were carried out on a 4-valve S.I. (spark ignited) gasoline engine, in which, the controllable quasi-homogenous mixture inside the cylinder made by controllable injection realized fast quasi-homogenous mixture combustion. The catalyst was fixed inside the vent-pipe of the engine, heated by electrical heater. The products after catalytic reaction were on-line analyzed with an exhaust analyser (MW56-AVL DIGAS 4000 LIGHT). The entire equipment of the catalytic assessment experiments is graphed elsewhere [20].

\subsection{In situ DRIFTS Study}

In situ DRIFT spectra were recorded on a NEXUS 670FTIR (Thermo Nicolet), equipped with a liquid $\mathrm{N}_{2}$ cooled high sensitivity MCT detector. The Ir/ZSM-5/cordierite sample $(0.5 \mathrm{~g})$ was finely ground and placed in the reaction chamber. Prior to each experiment, the sample was heated in He flow at $600{ }^{\circ} \mathrm{C}$ for $1 \mathrm{~h}$, and then cooled to the desired temperature for taking a reference spectrum. All gas mixtures were fed at a flow rate of $50 \mathrm{ml} / \mathrm{min}$. All spectra were measured with a resolution of $4 \mathrm{~cm}^{-1}$ and with an accumulation of 100 scans.

\section{Results and discussion}

\subsection{Characterization of catalysts}

The synthesized Ir/ZSM-5/cordierite sample is characterized by XRD and SEM techniques (Fig. 1). In the XRD patterns, the typical peaks of both ZSM- 5 and cordierite substrate have been lined out. It is well demonstrated that ZSM-5 zeolite have been in situ synthesized on the cordierite substrate. From the SEM image, it is found that sandwich ZSM-5 zeolite crystals (about $5 \mu \mathrm{m}$ ) grow on cordierite substrate in high quality and completely cover the irregular surface of cordierite substrate. Some other textural properties of Ir/ZSM-5/cordierite catalyst were displayed in Table 1.

The typical TEM image of as-synthesized Ir/ZSM-5/ cordierite is shown in Fig. 2. From the figure, it is seen that well-crystallized ZSM-5 zeolites with clear lattice structure connected tightly with cordierite substrate. No iridium species could be observed in the TEM images, probably due to the low iridium loading and high dispersion.

In monolithic Ir/ZSM-5/cordierite, ZSM-5 zeolite is not only the coatings on substrate but also the direct support of iridium: ZSM-5 zeolite coatings act as a bridge connecting cordierite substrate and active component iridium. On one side, by in situ synthesis, crystallization of ZSM-5 zeolite occurs not only on the external surface of cordierite substrate but also on the internal surface of cordierite [21]. Good stability and accessibility of ZSM-5 zeolite on cordierite substrate can be achieved $[21,22]$. On the other side, ZSM-5 coatings are good support for iridium species. The use of ultra weak $\mathrm{H}_{2} \mathrm{IrCl}_{6} \cdot 6 \mathrm{H}_{2} \mathrm{O}$ solution for wet impregnation allows a homogenous deposition of anionic $\mathrm{IrCl}_{6}^{2-}$ and thus an improved dispersion of Ir species. After calcinations in the air, $\mathrm{HCl}$ is released and $\mathrm{IrO}_{\mathrm{x}}$ clusters are formed. Generally, iridium tends to form volatile oxides, and the use of Ir-containing catalyst always suffers from severe loss of activity, or even cause a second pollution to the environment at relative high temperatures $[23,24]$. Here, the iridium in Ir/ZSM-5/cordierite might be stabilized and loss of active component iridium in the catalyst could be avoided to a great extend. In fact, no iridium loss is observed after 30 hours' catalytic reaction $\left(400{ }^{\circ} \mathrm{C}\right.$, GHSV $=30,000 \mathrm{~h}^{-1}$ ) and the iridium loading in catalyst 

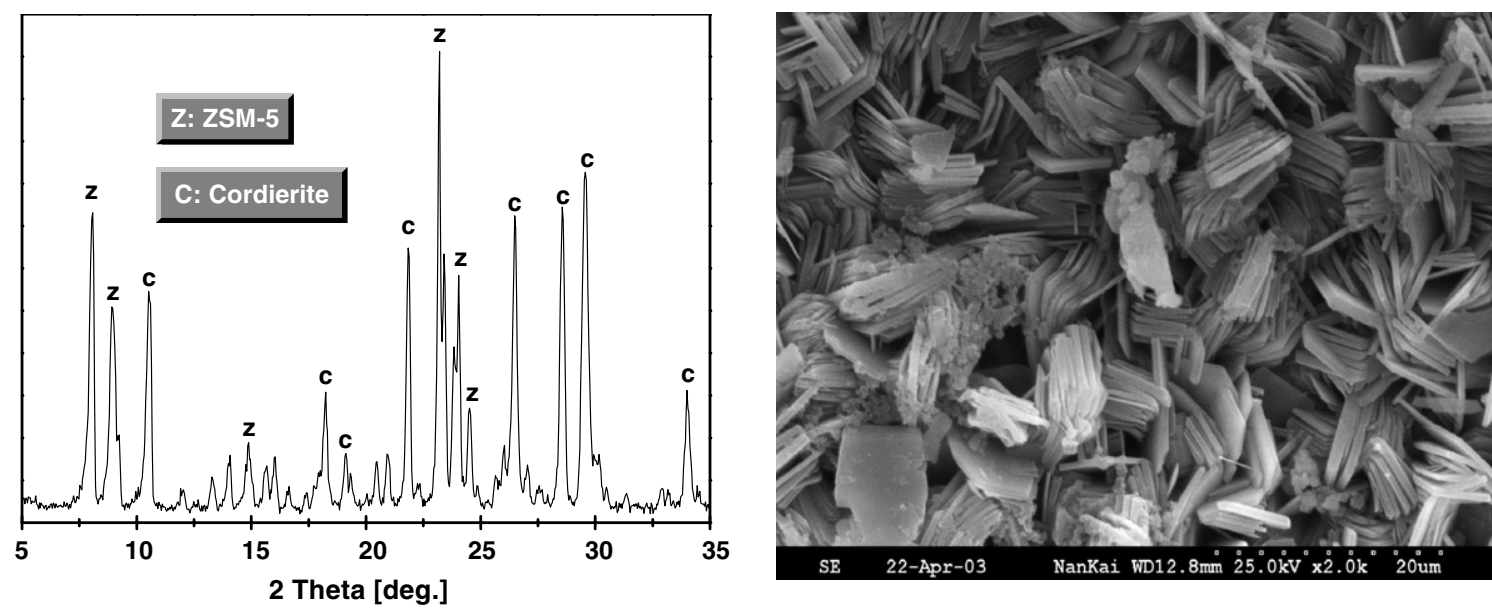

Fig. 1. XRD patterns (left) and SEM image (right) of Ir/ZSM-5/cordierite.

Table 1

Textural properties of Ir/ZSM-5/cordierite catalysts

\begin{tabular}{lllll}
\hline Catalyst & $\begin{array}{l}\text { BET surface } \\
\text { area }_{\left(\mathrm{m}^{2} / \mathrm{g}\right)}\end{array}$ & $\begin{array}{l}\text { ZSM-5 loading } \\
\left(\mathrm{wt}^{\mathrm{a}} \%\right)^{\mathrm{a}}\end{array}$ & $\begin{array}{l}\mathrm{Si} / \mathrm{Al} \\
\text { ratio }^{\mathrm{b}}\end{array}$ & $\begin{array}{l}\text { Ir loading } \\
(\mathrm{wt} \%)^{\mathrm{c}}\end{array}$ \\
\hline $\begin{array}{c}\text { Ir/ZSM-5/ } \\
\text { cordierite }\end{array}$ & 56 & 16.3 & 15.2 & 0.02 \\
\hline
\end{tabular}

${ }^{\mathrm{a}}$ In ZSM-5/cordierite.

${ }^{\mathrm{b}}$ Of ZSM-5 coatings, cordierite substrate excluded.

${ }^{c}$ In Ir/ZSM-5/cordierite monolith.

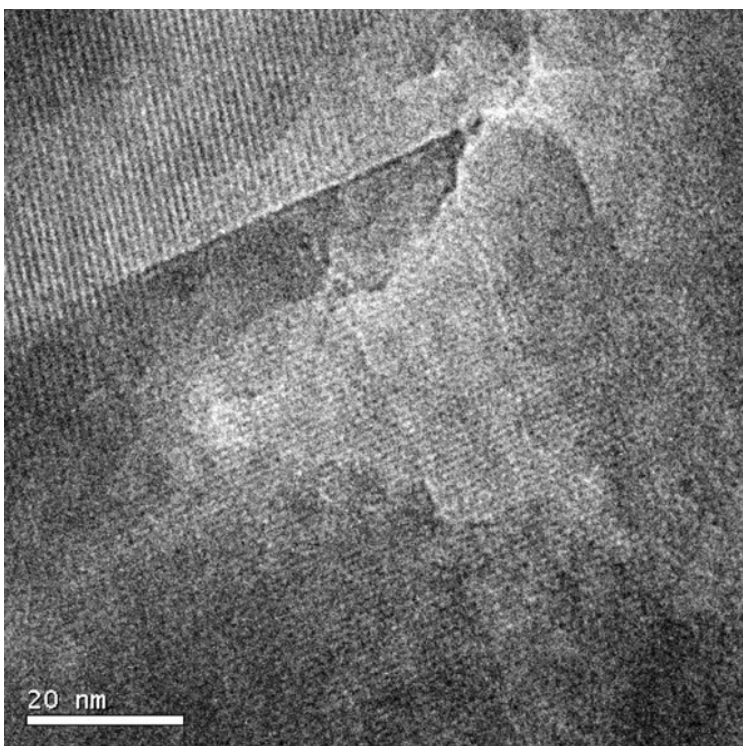

Fig. 2. TEM image of Ir/ZSM-5/cordierite monolith after calcinations.

can be kept at the initial level $(0.02 \%$,wt). Further experiments for testing iridium loss of different Ir-based catalysts are carried out. As seen in Table 2, iridium loss after long time aging on $\mathrm{Ir} / \mathrm{Al}_{2} \mathrm{O}_{3}$ was $43.90 \%$, while iridium loss was only $2.31 \%$ on Ir/ZSM- 5 with the similar initial iridium loading. Obviously, much better stability of iridium species on ZSM-5 support could be achieved.
Table 2

Testing of iridium loss for Ir-based catalysts

\begin{tabular}{lllc}
\hline Sample & \multicolumn{2}{l}{${\text { Iridium loading }(\mathrm{wt} \%)^{\mathrm{a}}}^{\text {Ir loss }(\%)}$} \\
\cline { 2 - 3 } & After calcination $^{\mathrm{b}}$ & After aging $^{\mathrm{c}}$ & \\
\hline $\mathrm{Ir} / \mathrm{ZSM}-5$ & 0.1601 & 0.1564 & 2.31 \\
$\mathrm{Ir} / \mathrm{Al}_{2} \mathrm{O}_{3}$ & 0.1417 & 0.0795 & 43.90 \\
\hline
\end{tabular}

${ }^{\text {a }}$ Determined by ICP, average of multiple metering.

b $550{ }^{\circ} \mathrm{c}, 6 \mathrm{~h}$, in the air.

c $500^{\circ} \mathrm{c}, 240 \mathrm{~h}$, in the air.

\subsection{Catalytic tests}

The catalytic test of Ir/ZSM-5/cordierite is carried on a real gasoline engine, in which, hydrocarbons and $\mathrm{CO}$ in exhaust are used directly as reductant for NOx reduction. The burning gasoline is commercially available from Shell gas station. The exhaust contained about $10 \%$ steam and $100 \mathrm{ppm} \mathrm{SO}$ from combustion of the commercial gasoline. Fig. 3 displays the status of the engine exhaust treated by Ir/ZSM-5/cordierite at the stoichiometric combustion condition $(\mathrm{A} / \mathrm{F}=14.7)$. Ir/ZSM-5/cordierite was activated at a temperature around $190{ }^{\circ} \mathrm{C}$ when NOx conversion (to $\mathrm{N}_{2}$ ) was about $50 \%$. At $260{ }^{\circ} \mathrm{C}$, the activity (for NOx reduction) of Ir/ZSM-5/cordierite reached its maximal value and the maximal NOx conversion was about $94 \%$. Afterwards, the activity (for NOx reduction) of Ir/ZSM-5/cordierite began to decrease. While, a positive effect of reaction temperatures on the conversion of both hydrocarbons and $\mathrm{CO}$ was observed: the maximal conversion of hydrocarbons $(100 \%)$ and CO $(98.4 \%)$ could be obtained since $280{ }^{\circ} \mathrm{C}$ and $240{ }^{\circ} \mathrm{C}$, respectively. It was observed that most pollutants NOx, HC and $\mathrm{CO}$ could be converted to harmless $\mathrm{N}_{2}, \mathrm{H}_{2} \mathrm{O}$ and $\mathrm{CO}_{2}$ (conversions $>90 \%$ ) at rather low temperatures between $250^{\circ} \mathrm{C}$ and $260^{\circ} \mathrm{C}$. Under common working condition of the engine, the purification results were satisfying and approaching to the commercial TWC. The high catalytic activity of commercial TWC was achieved under the co-function of active components $\mathrm{Rh}$, 


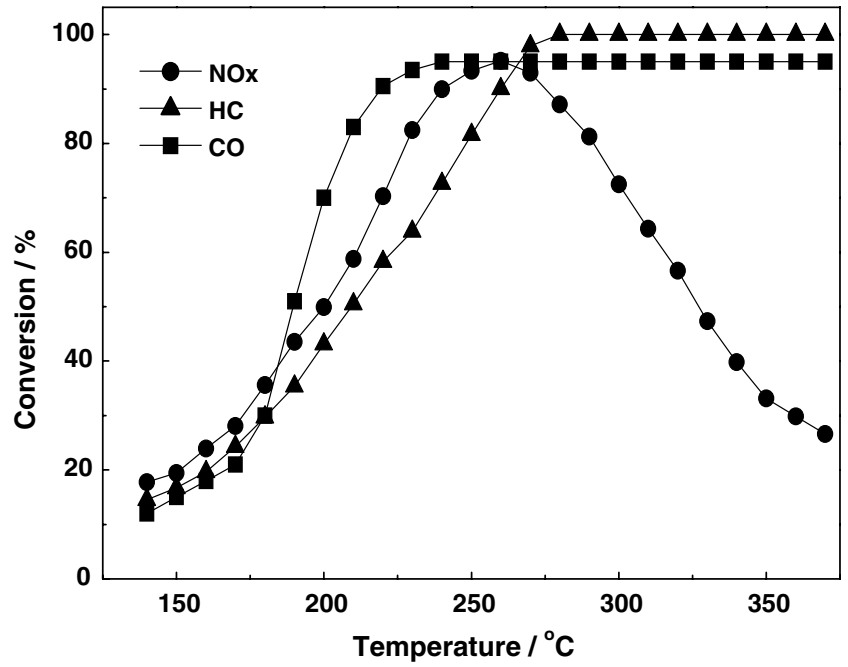

Fig. 3. Conversions of three main pollutants in exhaust varied with temperatures catalyzed by Ir/ZSM-5/cordierite. Working status of engine: $\mathrm{A} / \mathrm{F}=14.7$; Load $=0.3 \mathrm{Mpa}$; GHSV $=30,000 \mathrm{~h}^{-1}$; Exhaust before catalytic reaction: $\mathrm{NOx}=2310 \mathrm{ppm}, \mathrm{HC}=197 \mathrm{ppm}, \mathrm{CO}=0.45 \%$.

$\mathrm{Pt}, \mathrm{Pd}$ and some additives [3], while the catalytic activity of Ir/ZSM-5/cordierite could be achieved with single active component iridium at a very low content of about $0.02 \%$. Considering the simple preparation method and much lower price compared to TWC, Ir/ZSM-5/cordierite or modified Ir/ZSM-5/cordierites were expected to be good alternative for commercial TWC in treating automobile exhaust under stoichiometric combustion condition in the future.

Fig. 4 shows the catalytic efficiency of Ir/ZSM-5/cordierite as a function of GHSV at the constant reaction temperature of $290^{\circ} \mathrm{C}$. With GHSV increasing from $10,000 \mathrm{~h}^{-1}$ to $50,000 \mathrm{~h}^{-1}$, HC conversion was maintained at $100 \%$ while

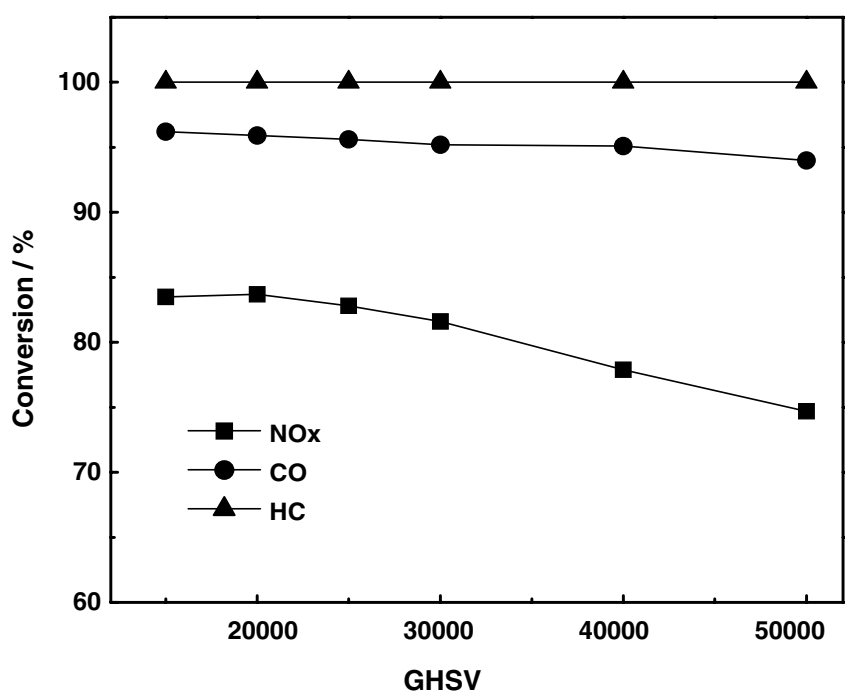

Fig. 4. Catalytic efficiency of Ir/ZSM-5/cordierite as a function of GHSV at the reaction temperature of $290^{\circ} \mathrm{C}$. Working status of engine: A/ $\mathrm{F}=14.7$; Exhaust before catalytic reaction: $\mathrm{NOx}=2310 \mathrm{ppm}$, $\mathrm{HC}=197 \mathrm{ppm}, \mathrm{CO}=0.45 \%$.
$\mathrm{CO}$ conversion and NOx conversion slightly declined from $96 \%$ to $93 \%$ and from $83 \%$ to $73 \%$, respectively. The catalytic efficiency of Ir/ZSM-5/cordierite is insensitive to the change in GHSV, which makes it potential catalyst for practical application of automotive exhaust.

Lean burn technique can not only greatly reduce specific oil consumption but also lead to much lower pollutants emission [25]. The curve of oil consumption varied with air fuel ratio of our testing engine is displayed in Fig. 5 and the pollutants concentration in exhaust at several different air fuel ratios are available in Table 3 . It is concluded that the optimal air fuel ratio is $17.5-19$ considering both economical and environmental factors. In this work, Ir/ ZSM-5/cordierite is tested as automobile exhaust catalysts under different lean conditions. As seen in Fig. 6, similar volcano-type curves of NOx conversion varied with reaction temperatures can be observed for different air fuel ratios. Ir/ZSM-5/cordierite was activated at the temperature of $190^{\circ} \mathrm{C}$ and the maximal NOx conversion was obtained at the temperature of about $260^{\circ} \mathrm{C}$ for all air fuel ratios studied. The difference only lied in the maximal NOx converted, which decreased with the increase of air fuel ratio. Since the oxygen concentration in exhaust increases

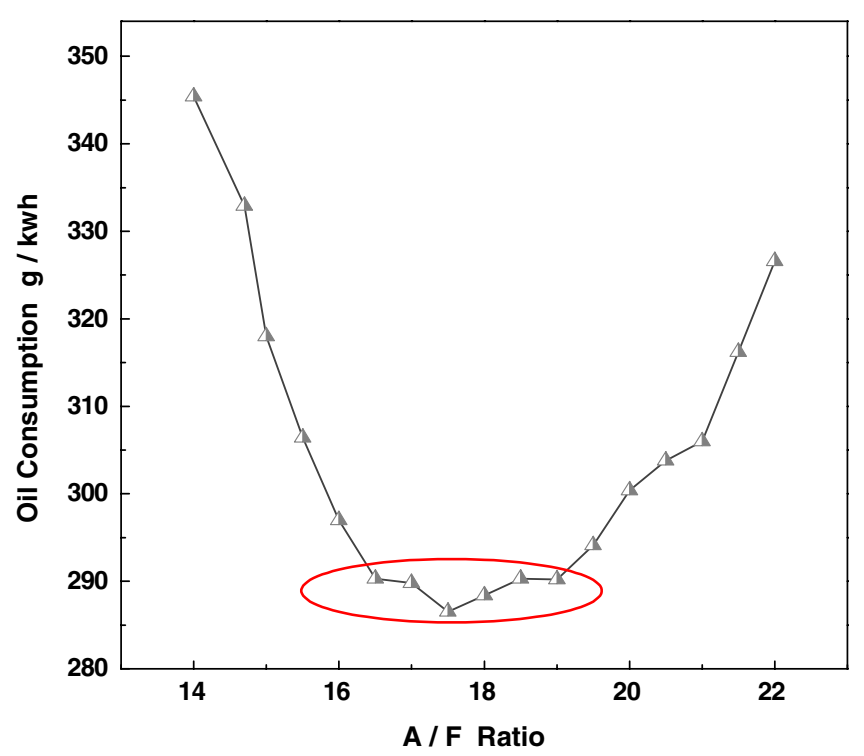

Fig. 5. Specific oil consumption of testing engine varied with air fuel ratio. Working status of engine: $\operatorname{Load}=0.3 \mathrm{Mpa}, \mathrm{GHSV}=30,000 \mathrm{~h}^{-1}$.

Table 3

Pollutants and oxygen concentrations in exhaust

\begin{tabular}{lllll}
\hline A/F ratio & \multicolumn{4}{l}{ Concentrations in exhaust gas } \\
\cline { 2 - 5 } & NOx $(\mathrm{ppm})$ & $\mathrm{CO}(\%)$ & $\mathrm{HC}(\mathrm{ppm})$ & $\mathrm{O}_{2}(\%)$ \\
\hline 14.7 & 2310 & 0.45 & 197 & 1.2 \\
15.5 & 1840 & 0.39 & 133 & 2.5 \\
16.5 & 1350 & 0.24 & 110 & 3.6 \\
17.5 & 1260 & 0.19 & 120 & 4.4 \\
18.5 & 720 & 0.16 & 124 & 5.2 \\
19.5 & 550 & 0.12 & 125 & 6.7 \\
\hline
\end{tabular}




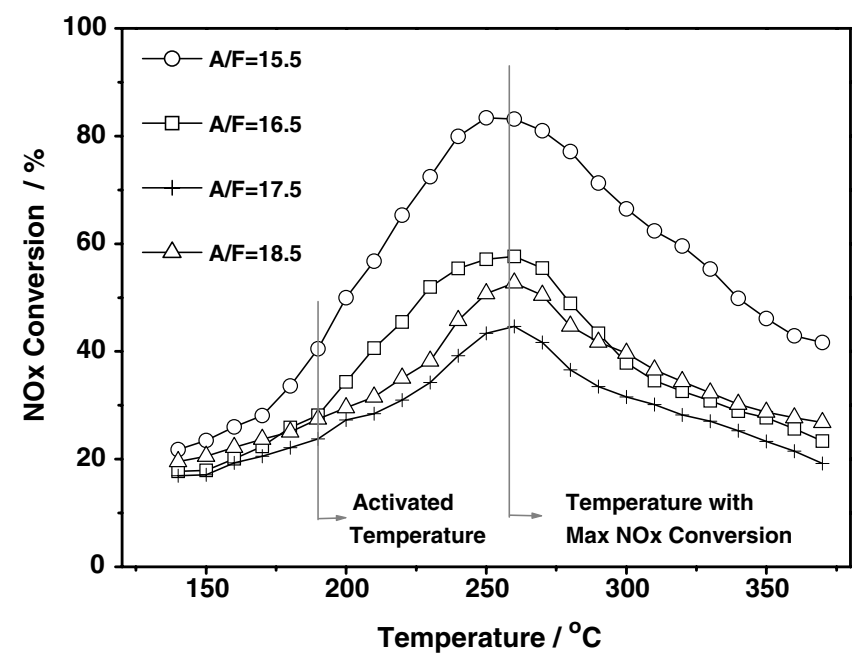

Fig. 6. NOx conversions varied with reaction temperatures catalyzed by Ir/ZSM-5/cordierite at different air fuel ratios. Working status of engine: Load $=0.3 \mathrm{MPa}, \mathrm{GHSV}=30,000 \mathrm{~h}^{-1}$.

with air fuel ratio (Table 3), it is concluded that maximal NOx converted decreases with increasing oxygen concentration. In our reaction system, the hydrocarbons concentration is quite low and is far not enough to reduce the NOx in the exhaust. So, carbon monoxide acts as the main reductant for NOx reduction and the following two reactions are considered to operate in lean conditions:

$2 \mathrm{CO}+2 \mathrm{NO} \rightarrow 2 \mathrm{CO}_{2}+\mathrm{N}_{2}$

$\mathrm{O}_{2}+2 \mathrm{CO} \rightarrow 2 \mathrm{CO}_{2}$

Excess oxygen is known to show great inhibition effect for NOx reduction on commercial TWC [26]. A comparison between maximal NOx conversion over Ir/ZSM-5/cordierite and commercial TWC (TWX ${ }^{\mathrm{TM}}$, Engelhard) at different air fuel ratios is shown in Fig. 7. It is seen that

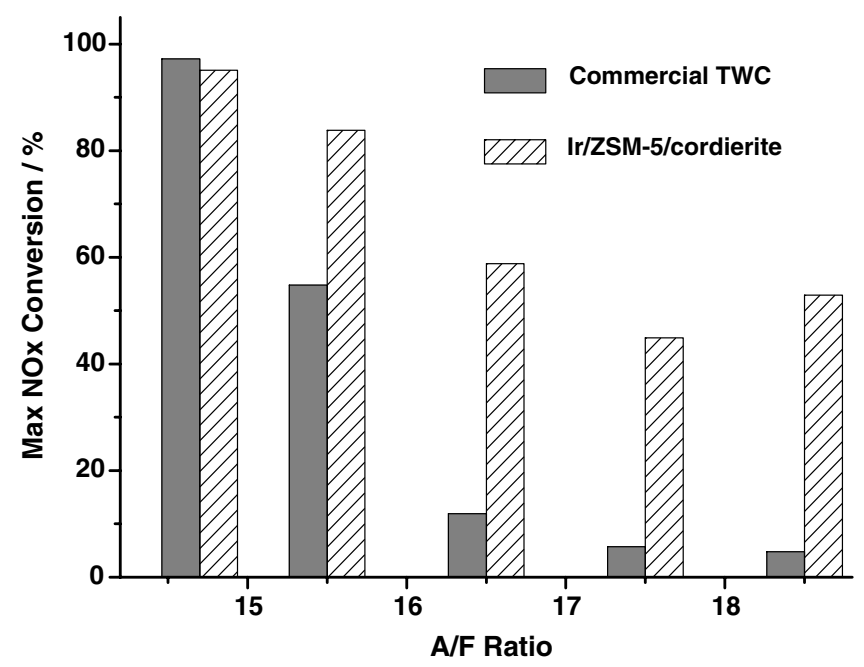

Fig. 7. Maximal NOx conversion varies with air fuel ratios over Ir/ZSM5/cordierite and commercial TWC. Working status of engine: Load $=0.3 \mathrm{Mpa}, \mathrm{GHSV}=30,000 \mathrm{~h}^{-1}$. though oxygen inhibition effect on NOx reduction can be observed over both catalysts, the inhibition extent on Ir/ ZSM-5/cordierite is much milder than that on commercial TWC. The catalytic performance of Ir/ZSM-5/cordierite is also compared to $\mathrm{Cu}-\mathrm{ZSM}-5 /$ cordierite, which is known as one of the best automobile exhaust catalysts under lean conditions [20]. Ir/ZSM-5/cordierite shows much better performance than $\mathrm{Cu}-\mathrm{ZSM}-5 /$ cordierite from the results in Fig. 8. HC and CO conversions over Ir/ZSM-5/cordierite were much higher than those over $\mathrm{Cu}-\mathrm{ZSM}-5 /$ cordierite at most temperatures studied. Maximal NOx conversion over Ir/ZSM-5/cordierite was about 5\% higher than that over $\mathrm{Cu}-\mathrm{ZSM}-5 /$ cordierite and more important, the temperature of maximal NOx conversion was $120^{\circ} \mathrm{C}$ lower, which was good for the purification of automobile exhaust automobiles in cold startup stage.

\subsection{Reaction mechanism}

To get a better understanding of $\mathrm{NO}$ reduction, the NO-CO- $\mathrm{O}_{2}$ reaction on Ir/ZSM-5/cordierite monitored with in situ DRIFT spectra, as displayed in Fig. 9.

In flowing $\mathrm{NO} / \mathrm{He}$, strong IR band at $2133 \mathrm{~cm}^{-1}$ is detected, which is assigned to the adsorbed $\mathrm{NO}^{+}$species on the Brønsted acid sites of ZSM-5 zeolite $\left(-\mathrm{NO}^{+}\right)$[27]. Some weak IR bonds can also be observed: bonds at $1900 \mathrm{~cm}^{-1}$ and $1850 \mathrm{~cm}^{-1}$ assigned to NO linearly adsorbed as $\mathrm{NO}^{\delta+}$ onto iridium crystallites and iridium atoms influenced strongly by the support respectively [28]; bonds at $1604 \mathrm{~cm}^{-1}$ and $1625 \mathrm{~cm}^{-1}$ assigned to bridged nitrato species adsorbed on cation sites in ZSM-5 zeolite from $-\mathrm{NO}^{+}$and adsorbed $\mathrm{O}$, similar to that formed on $\mathrm{Cu}$ site of $\mathrm{Cu}-\mathrm{ZSM}-5$ [29]. When $\mathrm{CO}$ is introduced, a strong IR bond at $2169 \mathrm{~cm}^{-1}$ can then be observed, which should be assigned to $-\mathrm{NCO}$ species adsorbed on iridium

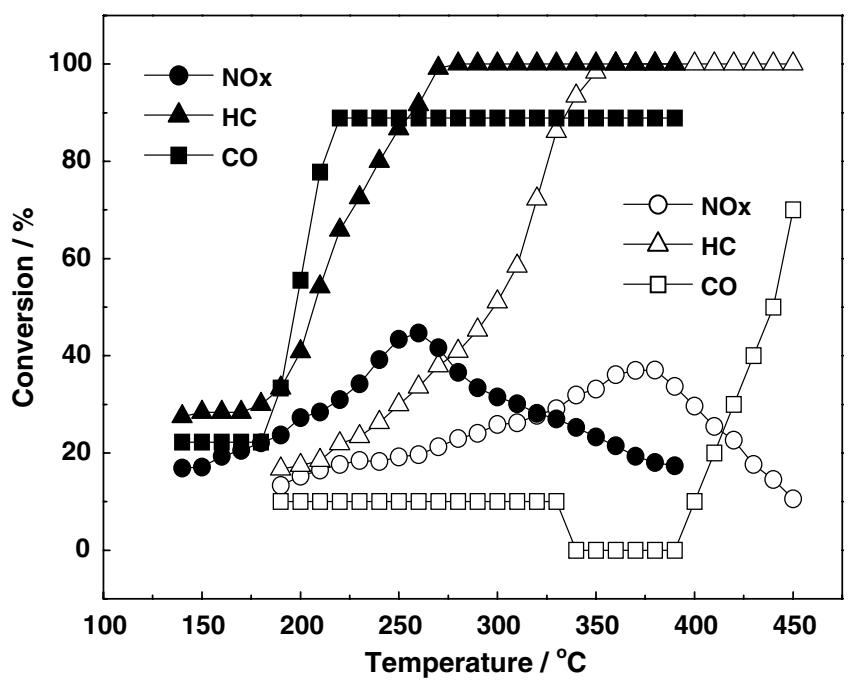

Fig. 8. Catalytic performance of Ir/ZSM-5/cordierite (filled symbols and $\mathrm{Cu}-\mathrm{ZSM}-5 /$ cordierite (open symbols) $(0.60 \% \mathrm{Cu}$ loading, over exchanged) as automotive exhaust catalysts under lean condition. Working status of engine: $\mathrm{A} / \mathrm{F}=17.5$; $\mathrm{Load}=0.3 \mathrm{Mpa}$; GHSV $=30,000 \mathrm{~h}^{-1}$. 


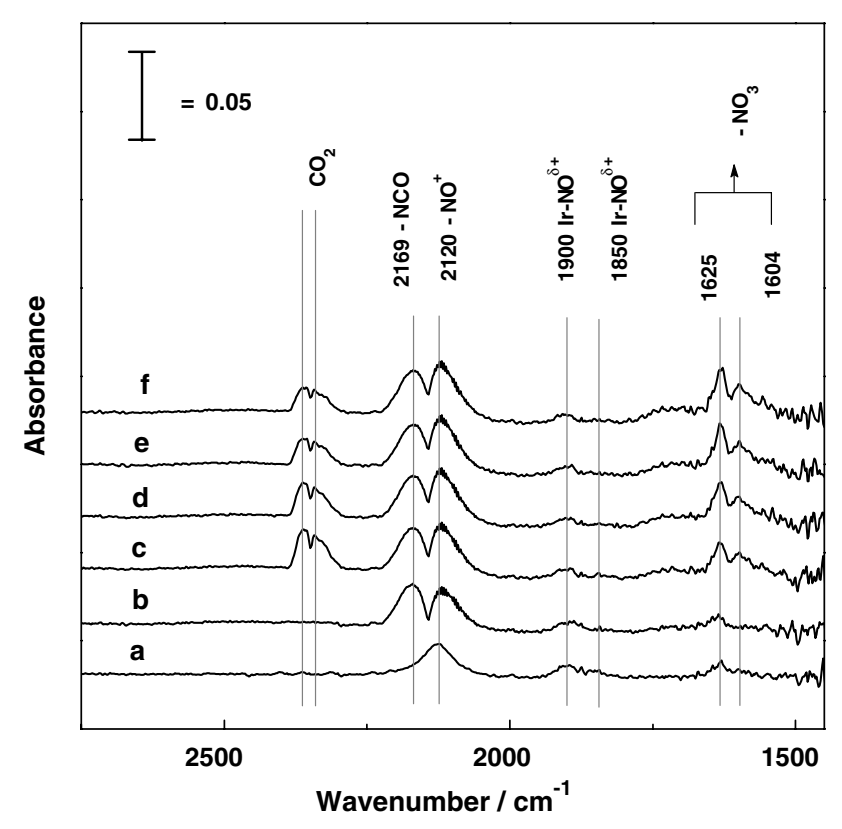

Fig. 9. DRIFTS study of adsorbed species formed on Ir/ZSM-5/cordierite in a flow of (a) $1000 \mathrm{ppm} \mathrm{NO}$, (b) $1000 \mathrm{ppm} \mathrm{NO}+1000 \mathrm{ppm} \mathrm{CO}$, (c) $1000 \mathrm{ppm} \mathrm{NO}+1000 \mathrm{ppm} \mathrm{CO}+1 \% \mathrm{O}_{2}$, (d) $1000 \mathrm{ppm} \mathrm{NO}+1000 \mathrm{ppm}$ $\mathrm{CO}+2.5 \% \mathrm{O}_{2}$, (e) $1000 \mathrm{ppm} \mathrm{NO}+1000 \mathrm{ppm} \mathrm{CO}+5 \% \mathrm{O}_{2}$, (f) $1000 \mathrm{ppm}$ $\mathrm{NO}+1000 \mathrm{ppm} \mathrm{CO}+10 \% \mathrm{O}_{2}$ with He balance at $250{ }^{\circ} \mathrm{C}$.

species $[30,31]$. Notable, no bonds corresponding to $\mathrm{CO}$ species adsorbed on iridium of Ir/ZSM-5/cordierite could be observed in flowing $\mathrm{CO} / \mathrm{NO} / \mathrm{He}$, different from the results reported on $\mathrm{Ir} / \mathrm{Al}_{2} \mathrm{O}_{3}$ [28] or $\mathrm{Ir} / \mathrm{SiO}_{2}$ [31]. Based on the DRIFTS results, the main process for NO reduction on Ir/ZSM-5/cordierite catalyst was proposed as follows:

$$
\begin{aligned}
& \mathrm{NO}(\mathrm{g})+\mathrm{O}+\mathrm{H}^{+} \rightarrow-\mathrm{NO}^{+}+\mathrm{H}_{2} \mathrm{O} \\
& -\mathrm{NO}^{+}+2 \mathrm{O} \rightarrow-\mathrm{NO}_{3} \\
& -\mathrm{NO}^{+} \rightarrow-\mathrm{NO}^{\delta+} \\
& -\mathrm{NO}^{\delta+} \rightarrow \mathrm{N}+\mathrm{O} \\
& \mathrm{N}+\mathrm{CO}(\mathrm{g}) \rightarrow-\mathrm{NCO} \\
& -\mathrm{NCO}+\mathrm{O} \rightarrow 1 / 2 \mathrm{~N}_{2}+\mathrm{CO}_{2} \\
& -\mathrm{NCO}+\mathrm{NO}(\mathrm{g}) \rightarrow \mathrm{N}_{2}+\mathrm{CO}_{2}
\end{aligned}
$$

In the first step, gaseous $\mathrm{NO}$ together with $\mathrm{O}$ adsorbs as $-\mathrm{NO}^{+}$species on Brønsted acid sites of ZSM-5 zeolite. Then, $-\mathrm{NO}^{+}$species can be further oxidized by $\mathrm{O}$ to form bridged nitrato species $-\mathrm{NO}_{3}^{-}$, or migrates to adjacent acceptor iridium sites strongly interacting with ZSM-5 support as $-\mathrm{NO}^{\delta+}$. When migrated to iridium, $-\mathrm{NO}^{\delta+}$ will dissociate to $\mathrm{N}$ and $\mathrm{O}$ immediately [17]. The adsorbed $\mathrm{N}$ then reacts with gaseous $\mathrm{CO}$ to form isocyanate $-\mathrm{NCO}$ species. The $-\mathrm{NCO}$ species are regarded as high active reaction intermediate of $\mathrm{NO}-\mathrm{CO}$ reaction and they can react with $\mathrm{NO}$ or $\mathrm{O}$ to produce $\mathrm{N}_{2}$ and $\mathrm{CO}_{2}[32,33]$.

When $1 \%$ oxygen is introduced into the $\mathrm{NO}-\mathrm{CO}$ reaction system, the intensity of IR bonds at $1604 \mathrm{~cm}^{-1}$ and $1625 \mathrm{~cm}^{-1}$ (corresponding to bridged nitrato species) increase, while the intensity of IR bond at $2169 \mathrm{~cm}^{-1}$ (corresponding to species) remains unchanged. Besides, multiple IR bonds between $2300 \mathrm{~cm}^{-1}$ and $2400 \mathrm{~cm}^{-1}$ corresponding to adsorbed $\mathrm{CO}_{2}$ species [34] appear. With oxygen concentration increase from $1 \%$ to $10 \%$, the intensity of IR bonds corresponding to $-\mathrm{NO}_{3}$ species increases obviously while the intensity of IR bonds corresponding to $-\mathrm{NCO}$ species does not show obvious change. Increasing oxygen concentration results in greater negative effect on NO reduction, in consistent with the catalytic results (Fig. 6). However, it is also seen that oxygen will not suppress the formation of $-\mathrm{NCO}$ species, which are the main reaction intermediates for NO reduction. So, Ir/ZSM-5/cordierite exhibits considerable catalytic activity for NO reduction even under lean conditions.

\section{Conclusion}

By in situ synthesis, ZSM-5 zeolites grew on the surface of honeycomb cordierite substrate and formed ZSM-5/cordierite. Trace iridium was introduced to ZSM-5/cordierite by wet impregnation and Ir/ZSM-5/ cordierite became a stable monolith. Ir/ZSM-5/cordierite exhibited quite good catalytic performance for the reduction of nitrogen oxides from automobile exhaust under both stoichiometry combustion and lean conditions. The NO-CO- $\mathrm{O}_{2}$ reaction on $\mathrm{Ir} / \mathrm{ZSM}-5 /$ cordierite catalyst was monitored using in situ DRIFT spectra and the isocyanate species were observed as the reaction intermediates for NO reduction.

\section{Acknowledgements}

This work was financially supported by National Natural Science Foundation of China (20573059) and GM-China Scientific Research Fund (50322261).

\section{References}

[1] J.H. Seinfeld, Science 243 (1989) 745.

[2] K.C. Taylor, Catal. Rev. Sci. Eng. 35 (1993) 457.

[3] M. Shelef, R.W. McCabe, Catal. Today 62 (2000) 35.

[4] J. Kašpar, P. Fornasiero, N. Hickey, Catal. Today 77 (2003) 419.

[5] A. Fritz, V. Pitchon, Appl. Catal. B 13 (1997) 1.

[6] S. Bhattacharyya, R. Das, Int. J. Energy Res. 23 (1999) 351.

[7] Y. Traa, B. Burger, J. Weitkamp, Micropor. Mesopor. Mater. 30 (1999) 3.

[8] R.M. Heck, R.J. Farrauto, 221 (2001) 443.

[9] R. Burch, J.P. Breen, F.C. Meunier, Appl. Catal. B 39 (2002) 283.

[10] R. Burch, Catal. Rev. Sci. Eng. 46 (2004) 271.

[11] T. Nakatsuji, Appl. Catal. B 25 (2000) 163.

[12] C. Wögerbauer, M. Maciejewski, A. Baiker, Appl. Catal. B 34 (2001) 11.

[13] C. Wögerbauer, M. Maciejewski, A. Baiker, J. Catal. 205 (2002) 157.

[14] A.Q. Wang, L. Ma, Y. Cong, T. Zhang, D.B. Liang, Appl. Catal. B 40 (2003) 319.

[15] M. Haneda, T. Yoshinari, K. Sato, Y. Kintaichi, H. Hamada, Chem. Commun. (2003) 2814.

[16] Z.P. Liu, S.J. Jenkins, D.A. King, J. Am. Chem. Soc. 125 (2003) 14660. 
[17] Z.P. Liu, S.J. Jenkins, D.A. King, J. Am. Chem. Soc. 126 (2004) 10746.

[18] S. Khatua, G. Held, D.A. Kind, Surf. Sci. 586 (2005) 1.

[19] L.D. Li, J.X. Chen, S.J. Zhang, N.J. Guan, M. Richter, R. Eckelt, R. Fricke, J. Catal. 228 (2004) 12.

[20] L.D. Li, J.X. Chen, S.J. Zhang, N.J. Guan, T.Y. Wang, S.L. Liu, Environ. Sci. Technol. 39 (2005) 2841.

[21] L. D Li, B. Xue, J.X. Chen, N.J. Guan, F.X. Zhang, H.Q. Feng, D.X. Liu, Appl. Catal. A 292 (2005) 312.

[22] M.A. Ulla, E. Miro, R. Mallada, J. Coronas, J. Santamaria, Chem. Commun. (2004) 528

[23] F. Zereini, F. Alt, Anthropogenic Platinum-group Element Emissions, Springer Berlin, Germany, 2000.
[24] H.S. Gandhi, G.W. Graham, R.W. McCabe, J. Catal. 216 (2003) 433.

[25] F. Garin, Catal. Today 89 (2004) 255.

[26] G. Djéga-Mariadassou, Catal. Today 90 (2004) 27.

[27] K. Hadjiivanov, J. Saussey, J.L. Freysz, J.C. Lavalley, Catal. Lett. 52 (1998) 103.

[28] F. Solymosi, J. Raskó, J. Catal. 62 (1980) 253.

[29] M.V. Konduru, S.S.C. Chuang, J. Catal. 196 (2000) 271.

[30] F. Solymosi, J. Raskó, J. Catal. 63 (1980) 217.

[31] M. Haneda, Pusparatu, Y. Kintaichi, J. Catal. 229 (2005) 197.

[32] J. Raskó, F. Solymosi, J. Catal. 71 (1981) 219.

[33] R.Q. Long, R.T. Yang, J. Phys. Chem. B 103 (1999) 2232.

[34] B. Bonelli, B. Civalleri, B. Fubini, P. Ugliengo, C.O. Arean, E. Garrone, J. Phys. Chem. B 104 (2000) 10978. 